\title{
Dimensions of Water Scarcity: A Tussle between Supply and Demand
}

\author{
Ar. Sharduli T Joshi
}

\begin{abstract}
Fifty years ago, the population of the world was almost half than today. Fewer calories were consumed, less meat consumption, and thus less water was required to produce food. There was limited pressure imposed on the environment and hence water consumption was also in control.

Today the struggle for scarce water resources in many places is unavoidable. Many river basins are unable to fulfill all the demands of water even for their rivers to reach the sea. Further extraction of water for human use is not possible because limits have been reached and in many cases breached. Basins are effectively "closed," with no possibility of using more water. The lack of water is thus a cause of worry to produce food for hundreds of millions of people.

When any region suffers from water crowding and have increasing water demands, its first and common most reaction is to tap more water from surface as well as ground by building new hydraulic projects or increase capacity of existing ones.

And so the tussle between supply and demand begins. The objective of the paper is to shed light on driving forces of water scarcity, avoidable and unavoidable aspects, and immediate responses like developing water resources, reallocation between different sectors, conserving water resources, short and long term consequences of the same with respect to developing country like India. The paper will conclude with analysis of demand and supply of water with respect to Indian context and propose strategies for sustainable management of water resources.
\end{abstract}

Index Terms - Water supply, water demand, water crowding, reallocation, sustainable management

\section{INTRODUCTION}

The struggle for scarce water resources in many countries today including India is inevitable. Many river basins around the world are unable to fulfill all the demands of water even for their own rivers to reach the sea. Further extraction of water for human use is not possible because limits have been reached and in many cases breached. Several river basins are effectively "closed," with no possibility of using more water. The shortage of water is thus a cause of concern for production of food for hundreds of millions of people. Greater competition raises questions between states, countries as well as regions over allocation of water, which is benefited, between those upstream and those downstream.

Also, human beings are not the only ones who are using available water for themselves. The aquatic and terrestrial ecosystems are also dependent on fresh water for living. Ecosystem services are fragile and are vanishing due to the way in which we grow food. The climate is changing, affecting every aspect of neighborhoods, economies and ecological systems.

Assistant Professor, SMEF's Brick chool of Architecture, Savitribai Phule Pune University, Pune, Maharashtra, India
The trend lines shout out that we are not doing the right things. Inequity in the benefits of water use will increase between haves and have-nots to the loss of food production. The pollution and depletion of rivers and groundwater will continue. Also, abundant food grown at the aggregate global level does not mean there is enough food for everyone.

(Molden D., 2007) defined 'physical water scarcity' in regions lacking adequate water to fulfil its demands, specified by circumstances as the amount of water used compared to the available water resource ratio surpasses $70 \%$.

(Molden D., 2007) defines two types of water stresses which are as follows:

"Demand-driven water stress: when there is a high usage compared to the availability of water". (Molden D., 2007). In this situation open basins can accommodate more structures to tap utilizable flows to address increasing demand but after a certain point, a time comes when no more utilizable flow is left in the river basin i.e when the basin is set to be closed. Inspite of this, in many cases of closed river basins over allocation, exploitation continues and the water depletion exceeds the utilizable flow which leads to a potentially unsustainable situation

"Population-driven water shortage: when there are many people dependent on the availability of water". (Molden D., 2007) The rise in population directly affects the consumption of water. This is because even if the demand is incresing the amount of water available naturally does not change but infact goes on reducing day by day. Also, the amount of rainfall received fairly remains the same each year thereby delpeting the water resources with increased consumption. One of the main cause of population explosion is pollution of rivers and lakes which alsoleads to water scarcity.

The management of river basins is going to be more difficult as these basins are moving towards higher form of water crowding. Well defined water policies, water rights, management and governance are required to deal with these closed or closing basins.

\section{DRIVING FORCES}

According to Figure 1, the driving forces of water scarcity (being the "imbalance between water supply and water demand") comprises of mainly population growth, migration, land use changes, climate change, and changes in economic activities leading to changes in societal needs. These are significant drivers, which exert direct stress by altering water availability (rainfall, evaporation, evapotranspiration, etc.) or indirectly by upgrading production patterns, changing 
consumption patterns on water resources, ultimately affect the aquatic environment. (Strosser P., et.al., 2012)

Land use change in the agricultural sector is one of the foremost drivers in water deficit areas. Its share can reach up to $85 \%$ of water use as a result of the high dependence on irrigation. Due to the current advanced research and development in the sector of irrigation techniques, effective fertilizers and insecticides, improved seed varieties etc., development of irrigated areas have increased extensively. This expansion in irrigated areas is the reason for series of adverse environmental impacts, viz. over-pumping of fragile aquifers, water logging and increased soil salinity.

Indeed, a WWF and SEO/ Birdlife (2010) study highlighted that the level of subsidies allocated to the agricultural sector in a region is inversely correlated to its environmental situation (in terms of overexploitation of aquifers or nitrate and phosphate pollution originating from agricultural practices), as innovation, motivation and subsidies are given to farmers to use fertilizers and pesticides to increase agricultural produce that imposes higher pressures on the environment. (Strosser P., et.al., 2012)

Along with these, people expect more water for their daily needs like drinking, food production, recreation and aesthetics. There are political as well as other pressures with societal demands, and hydraulic development is at the prime importance of the political agenda. (Falenmark M, Molden D., 2008)

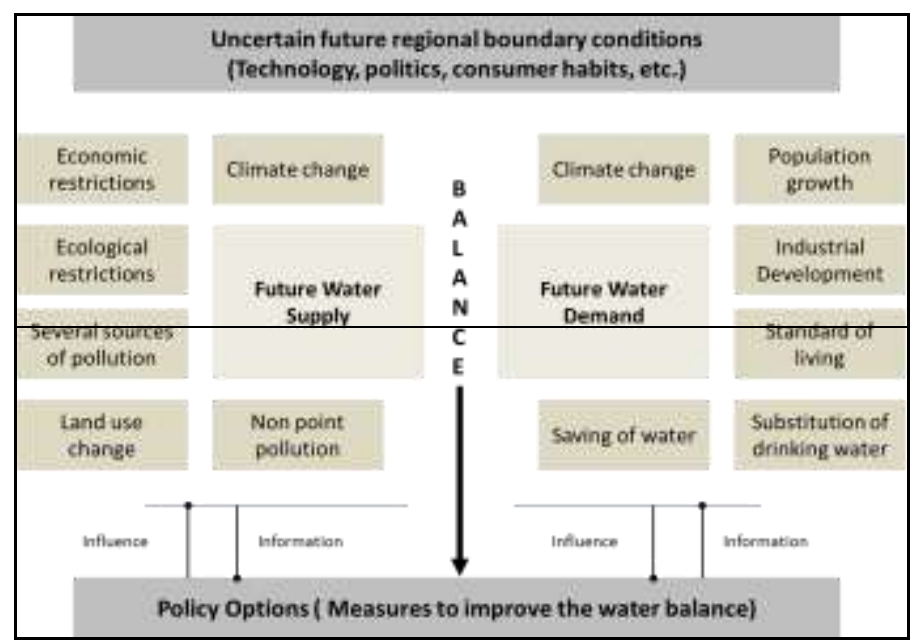

Fig 1: Driving forces of water supply and demand

Source: (Mall R.K, Gupta A., 2006)

\section{A. Avoidable and unavoidable}

Many of the drivers mentioned above with respect to water crowding are sometimes very tough to avoid. The priorities of developing countries like India are water development for poverty reduction, water for drinking and other purposes, hygiene and health, industrial expansion which is considered to be income and employment generator, also for food production as developing countries need to be self-sufficient and reduce import of food from other countries. To a certain extent neither we can avoid climate change nor control precipitation, discharge or runoff hence. This may lead to increase in the speed of the phenomenon of closure in regions with less rainfall where climate is becoming dry year by year.
Some of these driving forces can certainly be avoided with appropriate planning. Several decisions responsible for over tapping and over building in river basins, supporting extensive use of water due to unsustainable and unfair distribution, highlighted by (Molle F., 2006) are possible to be moderated. (Falenmark M, Molden D., 2008)

\section{CONSEQUences}

Some of the reasons of acute water scarcity are discussed above, but before approaching to conclusions the difference between increasing water withdrawals and increasing consumptive water uses which deplete the water resources should be analysed. As drivers lead to increase in water demands, huge amount of water is tapped and withdrawn from the resources. On the other hand, waste water generation an over consumption of water leads to depletion of river flows and reduces its self-cleansing capacity, shrinking the water resource because of depletive water use and pollution due to increasing water demands. (Falenmark M, Molden D., 2008)

Most of the Effects of basin closure are not experienced immediately, they are long term and irreversible. Yet, long term social, environmental costs are rarely acknowledged. For example, Krishna River basin central in India started closing in and around the year 2007-2008 and during the year 2011 it was completely closed. Along with directly visible adverse effects of bad water quality and constantly decreasing water quantity on aquatic and terrestrial ecosystems, estuaries and coastal aquifers are suffering from sea water intrusion, ground water levels are falling down significantly, delta region is eroded and wetlands have degraded which can be clearly observed through the imageries in the figures 2 and 3.

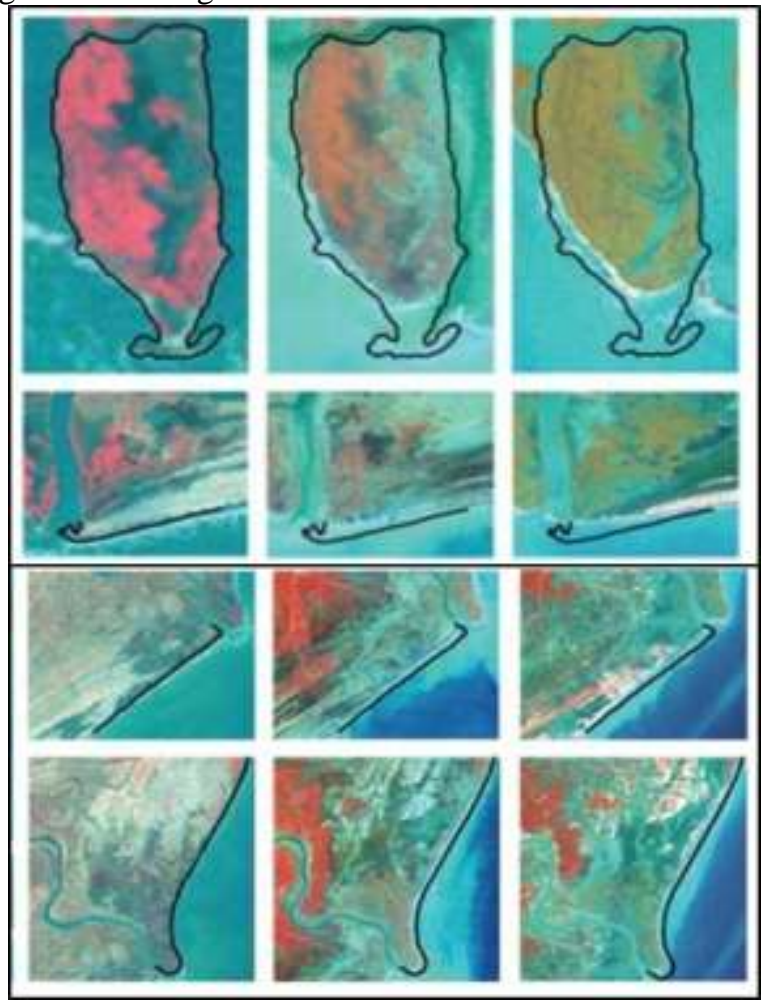

Fig 21: Google imageries of Krishna delta

Source: (Bharati, 2008) 


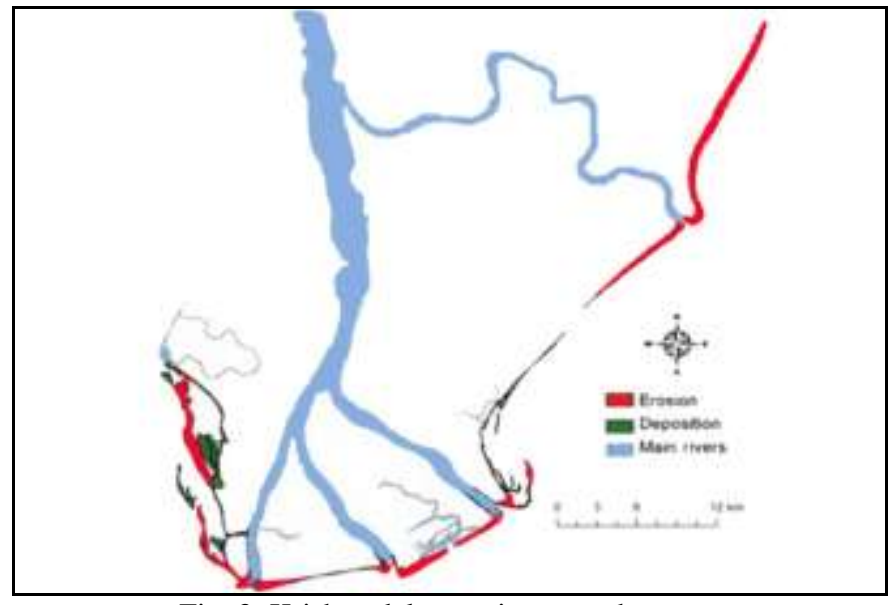

Fig. 3: Krishna delta erosion over the years Source: (Bharati, 2008)

(Smakhtin, Bharati L., 2008) inferred in his study with the help of Google imageries that river is unable to carry sediment load to the sea which is one of the functions of a river because of settlement of sediment load at the bottoms of dams and barrages. He further quotes that because of over tapping of water; river cannot maintain its speed which is also a reason for reduced sedimentation loads at deltaic regions.

The case of lower Jordan River Basin explained by (Aken, Molle F., Venot, 2009) states how land cover of the basin changed from 1950 to 2009. Earlier in 1950's even if surface water was used for irrigation extensively, there was abundant water flow to the sea as the irrigated area was only about $28 \%$ of the basin. Over the period, as development happened in irrigation sector, ground water was tapped, and almost total control over water resource was established. In 2009, $79 \%$ of basin was under irrigation, almost every drop of surface water was stored and ground water was also extensively tapped.

(Falenmark M, Molden D., 2008) says that lower Jordan basin is a closed basin where all the water users are inter connected and every drop of water is used by them and almost zero water flows from river. There is no water left for future generations and future demands will have to be met by either re allocating water within its users or transferring water from another basin by interlinking the rivers. If the current situation is not resolved, there will be no water left for environmental services which will lead to a disastrous situation.

\section{RESPONSES TO ACUTE WATER SCARCITY}

Within various sectors, agriculture and irrigation are the largest users of water in the world. Approximately $80 \%$ of the water is consumed and unfortunately misused or poorly managed by this sector.

Misuse of water in any of the sectors like domestic, industrial or agricultural, is a threat to sustainable development. Today, most of the countries are suffering from water crisis and question of averting the water crunch without hampering the development, rises in front of planners, leaders and policy makers.

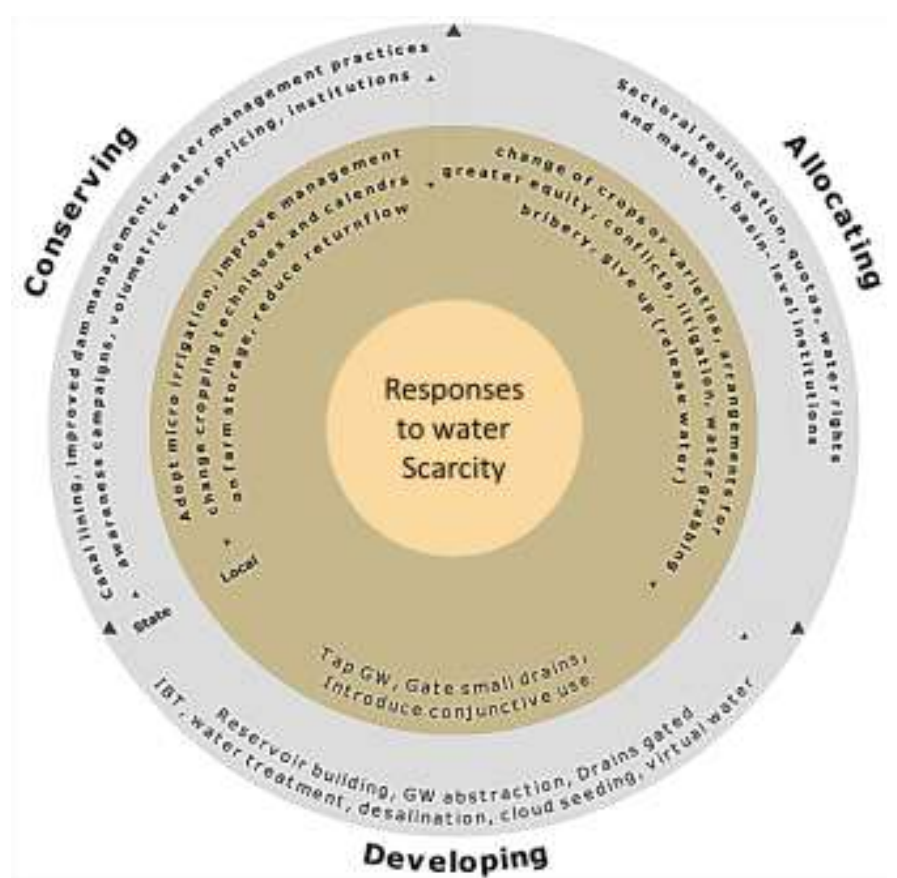

Fig 4: Three types of responses to water scarcity and the level Source: (Wester H, Molle, 2007), (Molle F., 2006)

\section{A. Development and Increasing Water Demands}

When any region suffers from water crowding and has increasing water demands, the first and foremost reaction is to tap more water from surface as well as the ground by building new hydraulic projects or increasing capacity of existing ones. (Molle F., 2006) also mentioned this situation of overbuilding of the basin as silent driver. The time required for construction is less for such project; the response is easier politically but in a long run leads to basin closure of rivers.

As stated earlier, state governments, private developers, development agencies are interested in mega hydraulic projects which are prestigious projects portraying concern for the people and vote bank. Socio economic aspect to develop water for overall economic development is normally the reason for approval of such projects without conflicting opinions. Huge amount of financial support and subsidies are given to irrigation schemes without sanctioning, which leads to illegal land use changes and it is capped under the name of development by implementing agencies.

These kind of unclear water rights and accounting systems may lead to over allocation of water to some of the influential water users, for personal profits. This happens because there is skewed governance, lack of enthusiastic participation, no transparency in the system to know the actual availability, sources, supplies, etc.

Private developers see a huge commercial gain in these projects. (Vennot, 2008) They turn these opportunities into very attractive projects and forget their long term effects.

\section{B. Water allocation}

(Molle F., 2006) suggests that reallocation of water is another important response to basin closure in basin management. Cities where more water was allocated earlier, and some of the water allocated is conserved then, the saved water can be reallocated 
to some other use or to environment considering equity, efficiency and economic development.

As drinking water has first priority in water allocations, there has been a trade-off in many river basins by agricultural to domestic use. Sometimes in over allocated basins, upstream users have to give up some part of their supply and usually this leads to disputes among the users both upstream and downstream. (Falenmark M, Molden D., 2008)

When disputes arise, strong institutional set up is essential to solve them as well as distribute water equitably among the users. This process is tedious and needs substantial amount of negotiations. These processes don't always succeed because sometimes these processes are manipulated financially by taking advantage of unclear water rights. Well defined water rights are very important while re allocating water resource equitably. But they are fussy most of the times to act as foundation of negotiations. (Falenmark M, Molden D., 2008) suggests that if water rights are properly transcribed, it will be easier for the institutions to mechanise capping trading, transferring of rights with less disputes among the users.

\section{Water conservation and accounting}

According to Figure 4, the most significant way towards finding solution to water crowding and scarcity is to conserve water. Along with conservation, accounting of the scarce water supply is required in order to understand the complex water flow network as well as to support the negotiations.

In the water flow network it is essential to understand the rate of water depletion through evaporation, evapotranspiration, polluted water etc. along with water availability and supply. The percentage of water which should be recycled or reused to keep utilisable flow for other important functions can affect reallocation of utilisable flows according to depletion. (Falenmark M, Molden D., 2008)

\section{DEMAND AND SUPPLY SIDE APPROACHES}

\section{A. Demand management}

Demand management is difficult to execute and according to (Falenmark M, Molden D., 2008) a proper way towards water saving is demand management with respect to water users which can minimize over use of water and hence can reduce water crowding. It is the only way to achieve water resource management.

This approach also gives some of the motivations like capping or taxing the amount of water used or supplied or water trading. Some of the water saving mechanisms in agricultural irrigation is drip, sprinkle systems and also policies which regulate flow of water in different sectors.

But in closed basin, most of the times, amount of actual saving retrieved is very less. (Molden D., 2007), (Venot,et.al., 2008)

In order to save some amount of water through irrigation sector, pressure on agricultural produce to curtail demands of population which is constantly increasing and consumption patterns with less water is unavoidable. When water is regulated, and some amount of water is allocated to some other sector instead of agriculture, then research and development regarding advance technologies should be provided to the farmers to increase the productivity with less water.

Demand management thus seems to be a way to slow down process of basin closure, but to compensate this water; some basins might have to use more water in order to fulfil ever increasing food and energy demands. (Fraiture, Molden D., Wichelns D., 2009)

\section{B. Supply side approaches}

Supply side solutions are those in which availability of water in a region is increased by using different sources to borrow or divert the water, inter basin water transfers being one of the examples. Closed basins are refilled with water from water rich or open basins with the help of canals or underground pipelines to minimize water crowding. This is quite an expensive option and has negative environmental impacts too. Nevertheless there are IBT (Inter Basin Transfer) proposals are approved, executed and operated.

India's NRLP (National river linking project) is said to be solution to droughts in some regions and floods in other at the same time. It could also be a way to reopen closed river basins. (Hall S., Slover, 2011)Some of the environmentalists on the other hand strongly oppose such grand schemes as they might alter hydrological patterns, ecosystem and endangered species of flora and fauna depending on original hydrology and ultimately lead climate change. Though such schemes have potential to provide the given region an economic uplifting it would be at the cost of ignoring social, environmental, hydrological considerations. (Biggs T., Gaur A., 2007),

\section{CONCLUSION}

In order to fulfill demands of population increase, uncertain weather, etc. obvious response of the governing bodies is to tap whatever water available without using it carefully. In order to bridge gaps between demands and supply, different practices are undertaken which do not sustain in the long term. Because of these long term practices, irreparable environmental losses have started emerging. The key challenge is to manage the available water resources in an environment friendly way without compromising the environmental requirements.

The authorities often try to concentrate on identifying potential gaps between water demand and water supply keeping in mind the needs of the future. Comprehensive plans are then prepared to strike a balance between the available supply and the anticipated societal demands, to remove the gap. These plans normally include predictions of anticipated levels of water use based on population growth, per capita and per hectare water use, and other variables that affect the demand. These estimates of future use are then compared with existing levels of available water, and the time when the disparity between anticipated levels of use and existing levels of supply is identified. Based on the magnitude and timing of this gap, measures and actions are then identified to close the gap and strike a balance between the supply and the expected demands.

The critical issue for planning, to be precise, is not closing any gap in the most literal sense as the quantity of water supplied always equals the quantity demanded or used. It is not practically possible for anyone or the population to use more 
water than what is actually available. The issue is rather that the amount of water requires for many purposes might exceed the available supplies in the future. For example, in many Middle Eastern households, water supply is severely controlled for most of the time, and such restrictions will grow with growing economies and populations. The places where current levels of water use are very low compared with the levels needed to avoid high economic and social cost, attention clearly focuses on closing the water supply "gap" between current and minimum acceptable levels of use. Also, where current levels of supply include sources that cannot last for longer period like mined ground water, it is impossible to strike a balance between supply and existing patterns of use forever. In these types of conditions to balance the demand and supply requires reallocation among different uses or developing newer supplies. Both of these steps may require significant environmental, social, or economic costs.

Since hydrological cycles, water users, aquatic and terrestrial ecosystems are interconnected; it is difficult to administrate river basins. Instead of giving scope to the development of the water, important fact is to give more emphasis to the water management. Instead of making new policies and governing bodies, collaboration and synchronised working of existing bodies is important. Grass root level actions in individual sub basins and water sheds, should lead to basin level priorities.

Well defined water policies, water rights, management and governance are required to deal with these closed or closing sub basins. Any plan for dealing with water scarcity should identify a range of alternatives for enhancing water supply and managing demand, provide cost estimates of every alternative, and distinguish alternative levels of water use where supplies and demands are in unison.

In developing countries like India evaluating broad policies to manage scarce water supplies is vital to identify the variables that have significant influence on the level of water use. It is equally important to understand the degree to which these variables can be managed or controlled, or whether to modify by doing the required research and development.

Finally, problems will intensify unless they are addressed and now.

\section{ACKNOWLEDGMENT}

I would like to express my genuine gratitude to my friend, mentor and husband Ar. Tejas Joshi for the constant support and patience, motivation towards my research study.

\section{REFERENCES}

[1] Aken, Molle F., Venot. (2009). Squeezed Dry: the Historical Trajectory of the Lower Jordan River Basin. CAB International, :20-43.

[2] Biggs T.,Gaur A. (2007). Closing of Krishna river basin: Irrigation, Stream flow depletion and macroscale hydrology. IWMI.

[3] Bharati, A. (2008). Analysis of the Inter-basin Water Transfer Scheme in India:A Case Study of Godavari-Krishna Link. NRLP.

[4] Falenmark M, Molden D. (2008). Wake up to realities of river basin closure. International journal of water resource development.

[5] Fraiture, Molden D., Wichelns D. (2009). Investing in water for food, ecosystems, and livelihoods: An overview of the comprehensive assessment of water management in agriculture. Agricultural Water Management, 495-501.
[6] Hall S., Slover. (2011). INTERBASIN TRANSFERS OF WATER. University of Georgia.: Proceedings of the 2011 Georgia Water Resources Conference.

[7] Mall R.K, Gupta A. (2006, June 25). Water resources and climate change:An Indian perspective. CURRENT SCIENCE, VOL. 90, pp. 1610-1626.

[8] Molden D. (2007). water for food water for life. Colombo: IWMI.

[9] Molle F. (2006, August). Why enough is never enough: The societal determinants of river basin 'overbuilding'. Stockholm: World Water Week.

[10] Smakhtin, Bharati L. (2008). Hydrological and Environmental Issues of Inter-basin water transfers in India Case of Krishna river basin. NRLP series 2 Paper 3.

[11] Strosser P., et.al. (2012). Gap analysis of the water scarcity and droughts policy in EU. European Commission.

[12] Vennot. (2008 ). Entre immobilisme et et adaptabilite Trajectoire d'evolution du bassin versant de la Krishna, Inde du sud. Paris: IWMI.

[13] Venot, Philippe J. (2008, September). Drawing water from thirsty lands, stories of the closing krishna river basin in south India. Oral presentation, Water availability, use and management. IWMI.

[14] Venot,et.al. (2008). The lower krishna basin trajectory: Relationships between basin development and downstream environmental degradation. IWMI.

[15] Wester H, Molle. (2007). River basin development and management. Water for food, water for life, IWMI, 585.

(Journal Online Sources style)

[16] Gray E. (2013). What is Global climate change? Retrieved March tuesday, 2013, from http://insights.wri.org/topic/green-infrastructure

[17] Greenpeace. (2010). greenpeace. Retrieved February monday, 2013, from http://www.greenpeace.org/india/en/

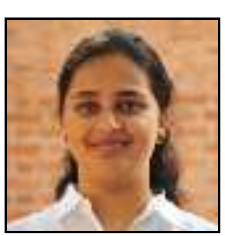

Ar. Sharduli Tejas Joshi

Date of Birth: 01/03/1988

Place : Pune

Registered Architect, Council of Architecture, India

\section{Educational Qualifications:}

B.Arch, Shivaji University, Kolhapur, India, 2010 M.Plan in environmental planning, CEPT University, Ahmedabad, India, 2013

\section{Professional Experience}

Sharduli has over 5 years of professional experience with specialization in urban and environmental planning and Architecture.

TRANIEE ARCHITECT, Fourth Dimension, Bangalore, India (2008)

ARCHITECT, Integrid Design Consultants, Pune, India (2010 - 2011)

Environmental planner, Urcon Consultants, Pune, India (2013-2014)

Assistant Professor, Brick School Of Architecture, Pune, India (2014 present)

Researcher, Brick Research and Design Cell (B-RADICL), Pune, India (2014 - present)

\section{Published articles}

'Contribution of Maharashtra in Krishna River Basin Closure' (India Water Portal ,2014)

'Politics of Water and Development' (Singapore, Springer, 2016) eBook ISBN

978-981-10-2138-1, Hardcover ISBN 978-981-10-2136-7, Series ISSN 2363-7633

Ar. Joshi has received a Gold medal for her studies in Bachelor of Architecture from Shivaji University, Kolhapur, India. 